UDC 332.1

JEL R10, R50

\title{
Strategic priorities of regional investment policy for advanced technological development (the case of Sverdlovsk region in Russia)
}

\author{
S.V. Vlasov \\ Ministery of the Agro-Industrial Complex and Consumer Market of Sverdlovsk Region, Ekaterinburg, Russia; \\ vlasovsv81@gmail.com
}

\section{ABSTRACT}

Relevance. The study investigates the structural and technological imbalances impeding Russian regions' transition to sustainable development.

Research objective. The study aims to describe and test an original methodological approach by using the case of a large industrial region in Russia - Sverdlovsk region. The proposed approach can provide a framework for the analysis of federal and regional strategies of long-term innovation and investment development, especially their industrial and spatial priorities.

Methods and data. The study relies on official statistical data covering a five-year period. A special focus was made on the strategies' key indicators, which were then compared with the long-term goals and targets of industrial and spatial development. The comparison of the key strategic indicators is supplemented by spatial analysis of regional investment activity by territory and type of investment.

Results. The study shows the need to align regional investment strategies with the strategies and policies of industrial, innovation and spatial development. For Sverdlovsk region, the study has revealed a pattern of spatial distribution of investment, which tends to concentrate in old industrial areas, that is, large cities and their agglomerations where the main production facilities are located.

Conclusion. The study identifies the drawbacks of regional strategies and shows why the strategies fail to fulfill their function in the general system of strategic planning.
\end{abstract}

\section{KEYWORDS}

regional investments, strategic landmarks, investment climate, scientific and technological development, technological breakthrough

\section{FOR CITATION}

Vlasov, S.V. (2021) Strategic priorities of regional investment policy for advanced technological development (the case of Sverdlovsk region in Russia). R-economy, 7(4), 276-288. doi: 10.15826/ recon.2021.7.4.024

\section{Стратегические приоритеты региональной инвестиционной политики для передового технологического развития (пример Свердловской области России)}

\section{С.В. Власов}

Министерство агропромышленного комплекса и потребительского рынка Свердловской области, Екатеринбург, Poсcия; vlasovsv81@gmail.com

\section{АННОТАЦИЯ}

Актуальность. В исследовании исследуются структурные и технологические дисбалансы, препятствующие переходу регионов России к устойчивому развитию.

Целью исследования является описание и апробация оригинального методологического подхода на примере крупного промышленного региона России - Свердловской области. Предлагаемый подход может обеспечить основу для анализа федеральных и региональных стратегий долгосрочного инновационного и инвестиционного развития, особенно их промышленных и пространственных приоритетов.

Методы и данные. Исследование опирается на официальные статистические данные за пятилетний период. Особое внимание было уделено ключевым показателям стратегий, которые затем сравнивались с долгосрочными целями и задачами промышленного и пространственного развития.

\section{КЛЮЧЕВЫЕ СЛОВА}

региональные инвестиции, стратегические приоритеты, инвестиционный климат, научно-техническое развитие, технологический прорыв 
Сопоставление ключевых стратегических показателей дополняется пространственным анализом инвестиционной активности регионов по территории и типу инвестиций.

Результаты. Исследование показывает необходимость согласования региональных инвестиционных стратегий со стратегиями промышленного, инновационного и пространственного развития. Для Свердловской области исследование выявило закономерность пространственного распределения инвестиций, которые имеют тенденцию концентрироваться в старопромышленных районах, то есть в крупных городах и их агломерациях, где расположены основные производственные мощности.

Вывод. В исследовании выявляются недостатки региональных стратегий и показано, почему стратегии не выполняют свою функцию в общей системе стратегического планирования.

\section{ДЛЯ ЦИТИРОВАНИЯ}

Vlasov, S.V. (2021) Strategic priorities of regional investment policy for advanced technological development (the case of Sverdlovsk region in Russia). R-economy, 7(4), 276-288. doi: $10.15826 /$ recon.2021.7.4.024

\section{Introduction}

The persisting structural-technological imbalance in Russia is a major impediment to the country's transition to a sustainable economy and technological leadership. The federal and regional governments are striving to bridge this imbalance through a set of measures meant to ensure advanced technological development and to stimulate fixed capital investment. Confronting this problem, however, requires the government to tackle two interrelated issues - the contradictions between the national innovation policy and its regional counterparts and the lack of salient dynamics in the indicators of innovation development in recent years. All of the above means that, first and foremost, it is necessary to align the goals of regional investment policies and strategies with the priorities of industrial and innovation development.

The article aims to evaluate regional investment activity by gauging the goals of advanced technological development set by national and regional strategies. Advanced technological development in this context implies acceleration of the pace of $R \& D$ progress through incubation and adoption of new technologies. It is particularly important to modernize the traditional sector by upgrading fixed assets and implementing the corresponding industrial and investment policies on the regional level.

The above-described research problem has determined the following tasks:

- to develop and test a methodology for analyzing goals, targets and priorities (their alignment and attainability) in state strategic planning in Russia;

- to compare planned indicators with the actual outcomes of the long-term strategies of investment, innovation and industrial development on the national and regional levels;
- to describe spatial patterns of investment in the region.

The main focus of the analysis is the investment processes in Sverdlovsk region, one of the core Russian regions for industrial production. It is also one of the top ten Russian regions in terms of gross investment, the volume of industrial output and gross regional product.

\section{Theoretical Framework}

In today's world, staying on top of technological advances is the key to economic leadership and sustainable development. In this light, what comes to the fore is the state policy that would give due regard to regional disparities in technological development (Komkov, 2003). In Russia, stimulation of the country's technological and socio-economic development was included into the national high-priority goals and aligned with other, more specific tasks, such as setting the country on a track to become one of the five largest economies in the world (Medvedev, 2018). Simachev et al. (2014), however, argue that there is a lack of efficient vertical and horizontal industrial policy-making, mainly due to the absence of feedback channels and the inadequacy of state institutions. This problem should be addressed by improving policy-making and policy implementation and by ensuring the high-quality of public administration.

In international studies, scholarly interest also centres on new regional industrial path development. Within the paradigm of evolutionary economic geography (EEG), Hassink et al. (2019) propose a new research agenda and outline four new avenues of research exploring the reasons why some regions succeed in nurturing the rise and further development of new paths while others fail. Bosák et al. (2018), in their discussion of the case of an old industrial city (Ostrava), show that in order to become more competitive, old industrial areas 
need to combine the following two approaches: 'assessment of intrinsic features of the structures' and consideration of the general global trends.

Studies on the development of science and technology often seek to identify the emerging technologies that would shape the future of economy and help countries stay ahead in global leadership (see, for instance, Borisov et al. (2018); Sidorov, 2020). An important contribution is made by foresight studies that provide a qualitative evaluation of the tech shifts and identify the priority areas of industrial development (Dezhina \& Ponomarev, 2016; Wagner \& Popper, 2003; Martin, 2010; Lane \& Kalil, 2005). Coates et al. (2002) highlight the need for clear, timely and inexpensive forecasts of technological development for different enterprises, including small-scale ones.

At the same time, as regional practice shows, despite the vast body of research describing the most promising technologies and markets to be included into regional strategies, there is still no sufficient understanding of how advanced technological development should be achieved. Moreover, in the last decade, Russian regions has experienced acute shortage of investment, which hampered the modernization of the fixed assets of capital-intensive industries.

Abalkin (2002) believes that the general flow of investment in fixed capital is determined by the government's ability to provide a clearly defined industrial and investment policy. Ivanter (2017) argues that technological development should go hand in hand with the modernization of the leading companies and other major manufacturing facilities. Thus, many Russian researchers see the task of stimulating fixed capital investment as crucial for the country's technological development (Barinova \& Zemtsov, 2015; Vlasov, 2015, 2018, 2019).

Vasiliev (2009) argues that the institutions imported from other countries and principles of the national innovation system do not fit the current needs of innovation development in Russia. On the other hand, Kotlyarova et al. (2010) contend that problems may stem from the lack of innovation culture. Golichenko (2011) states that, regardless of the national context, a well-designed system of measures for creating the conditions for fostering innovation can be quite effective, especially if combined with the restructuration of state institutions and connections between them. Golova \& Sukhovey (2011) observe that for a more efficient technological development, in- novation goals should be aligned with the goals of socio-economic policy and that due attention should be given to the spatial aspect.

In the research literature, Sverdlovsk region is widely considered to have everything it takes to become a centre of advanced technological development in the twenty-first century (Tatarkin et al., 2015; Bochko, 2011, 2015, 2019; Maslennikov, 2015). This region can drive the modernization of the Russian economy (Silin \& Animitsa, 2016, 2021). Silin and his associates (Silin et al., 2019) and Ivanova (2017) foreground the industrial localization pattern of Sverdlovsk region, where the main production facilities tend to concentrate around large cities, forming industrial agglomerations.

Analysis of regional investment activity should focus not only on the sectoral but also on spatial aspect. There is significant research evidence on the influence of strategic planning and agglomeration processes in large cities on investment flows (Gordon, 1993; Porter, 1996; Adams et al., 1999). Kemp (1992) showed how strategic planning in the public sector can help local governments plan the future of their municipalities proactively and better meet the public expectations concerning effective governance.

Comparative analysis of the priorities of innovation development in different economic sectors shows that these priorities are often not properly aligned with each other (Frolov, 2015). According to A.G.Aganbegyan (2021), a major 'technological turn' is required in Russia, since at the moment, the country is virtually a technology laggard: two-thirds of Russian enterprises are in need of thorough modernization. Aganbegyan (2021) argues that the only solution to the problem is a carefully designed strategic plan in combination with rigorous and high quality public administration.

The theory and practice of regional innovation systems are again high on the research agenda. There is a perceived need for a comprehensive analysis underpinning practical guidelines for more effective regional investment policies and strategies to boost technological development.

\section{Methods and Data}

This study takes as a point of departure the following assumption: in order to ensure the country's advanced technological development, policy-makers should align the long-term goals and priorities in the sphere of investment, innovation, industrial and spatial development 
of regions. The same should be done for the methods of implementation of the corresponding strategies and policies. Importantly, goal-setting should take into account the resources and other characteristics of the regions in question. The goals should be relevant, realistic and time-bound.

This study proposes a research methodology based on a comprehensive analysis of the national and regional statistical data on innovation and investment in the last 10 years in its spatial and sectoral aspects. The study examined the 'vertical' dimension of innovation and investment in Russia: from the macro- (national) to meso-level (regional - the case of Sverdlovsk region). The actual outcomes of the strategies were compared with the expected results in the sphere of $R \& D$, innovation and investment. The analysis also encompassed the 'horizontal' dimension of investment - the indicators and statistical data on municipalities and administrative-territorial districts of Sverdlovsk region, more specifically, the relative amount of private and state investment and the total amount of investment. The indicators for analysis were selected by using the parameters specified in the national and regional strategic planning documents ${ }^{1}$. The analysis took into account the agglomeration tendencies in the urban districts and the spatial distribution patterns of industrial production.

The study relies on the statistical data published by the Federal State Statistics Service (Rosstat) and its branch for Sverdlovsk Region and Kurgan Region as well as the Higher School of Economics, Ministry of Economy and Territorial Development of Sverdlovsk Region and other government agencies. The criterion for data selection was the availability of statistical data for the period when the strategies in question were implemented - from 2010 to 2020 - but not less than the last 5 years of the whole period in order to compare the expected results and the actual outcomes. The analysis of the spatial aspect of investment covered the period from 2010 to 2020 and focused on the concentration of investment and the spatial distribution of production facilities during the period of the innovation strategy's implementation. To examine the structure of investment, I looked at the statistics for 20002020, that is, the period preceding the adoption of

${ }^{1}$ See: Strategy of Innovation Development of the Russian Federation until 2020; Strategy of Innovation Development of Sverdlovsk Region until 2020; Investment Strategy of Sverdlovsk Region until 2035; Strategy of Industrial and Innovation Development of Sverdlovsk Region until 2035. the strategies and the period when these strategies were implemented. Thus, the analysis reflects the impact of these strategies on the key indicators in the long term.

The proposed methodology can be applied to gauge the long-term goals of innovation and investment development and to devise practical recommendations for regional governments concerning the choice of long-term investment priorities.

\section{Results}

Strategic goals and the highest-level indicators specified in the federal strategy create a vision of the future that guides regional governments and businesses in their own policy-making and goal-setting in the decades to come. Attainment of these goals and targets is not only a sign that the economic development is going in the right direction but also a measure of the quality and efficiency of national and regional strategic management.

Sluggish growth in the innovation indicators in recent years is confirmed by the analysis of the main outcomes of the Strategy of Innovation Development until $2020^{2}$. Sadly, the planned indicator values were not achieved and there was no positive dynamics in terms of innovation development (Table 1).

Like national-level indicators, the key socioeconomic indicators of Sverdlovsk region have demonstrated stagnant growth in recent years. The industrial production index has fallen from $106.2 \%$ in 2011 to 102.3 in 2020. A similar trend is observed in fixed capital investment, which dropped from $115.9 \%$ in 2011 to $90.1 \%$ in 2020 .

The aim of the region's own strategy of innovation development until 2020 was to stimulate the transition of the economy to the innovation-oriented model. Among the targets set by the regional strategy, it was planned to achieve an increase in the share of exports of innovative goods in the total volume of exports from $23.3 \%$ in 2011 to $40 \%$ in 2020. In 2020, however, this figure was only $7.5 \%$. The share of innovative goods, works and services of new-to-market organizations in the total volume of goods, works and services of industrial enterprises was $0.8 \%$. The actual indicator and its growth rates (see the diagram below) show that the strategy had obviously set the bar too high - the level of $40 \%$ by 2020 was clearly unrealistic.

2 Decree of the Government of the Russian Federation of 08.12.2011 No. 2227-p 'On the Approval of the Strategy of Innovation Development in the Russian Federation until 2020'. In: Collection of Legislation of the Russian Federation, 02.01.2012, No. 1, Article 216. 
Dynamics of the key indicators of the Strategy of Innovation Development

Table 1

of the Russian Federation until 2020

\begin{tabular}{|c|c|c|c|c|c|c|c|c|c|c|c|c|c|}
\hline № & Indicator & $\begin{array}{l}\text { Unit } \\
\text { of } \\
\text { meas. }\end{array}$ & 2010 & 2011 & 2012 & 2013 & 2014 & 2015 & 2016 & 2017 & 2018 & $\begin{array}{c}2019, \\
\text { trend } \\
\text { to plan } \\
2020\end{array}$ & $\begin{array}{c}2020 \\
\text { actual } \\
\text { (planned) }\end{array}$ \\
\hline 1 & $\begin{array}{l}\text { Invention activity coefficient } \\
\text { (the number of patent applica- } \\
\text { tions submitted in Russia per } \\
10 \text { thousand people) }\end{array}$ & units & 2.01 & 1.85 & 2.00 & 2.00 & 1.65 & 2.00 & 1.83 & 1.55 & 1.70 & $\downarrow_{1.59}$ & $\begin{array}{c}1.6 \\
(2.8)\end{array}$ \\
\hline 2 & $\begin{array}{l}\text { Share of organizations en- } \\
\text { gaged in technological inno- } \\
\text { vation in the total number of } \\
\text { organizations, including }\end{array}$ & $\%$ & 7.9 & 8.9 & 9.1 & 8.9 & 8.8 & 8.3 & 7.3 & $\begin{array}{c}7.5 \\
20,8^{*}\end{array}$ & $19,8^{*}$ & $\downarrow 21,6^{*}$ & $\stackrel{-}{(25)}$ \\
\hline & $\begin{array}{l}\text { extractive and manufactu- } \\
\text { ring industries, production } \\
\text { and distribution of power, } \\
\text { gas and water }\end{array}$ & & 9.3 & 9.6 & 9.9 & 9.7 & 9.7 & 9.5 & 9.2 & $\begin{array}{c}9.6 \\
19,6^{*}\end{array}$ & $18,5^{\star}$ & $\downarrow 20,0^{*}$ & 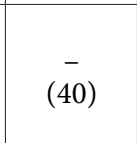 \\
\hline & $\begin{array}{l}\text { communications and other } \\
\text { ICT-related activities }\end{array}$ & & 10.8 & 9.9 & 10.3 & 10.3 & 9.5 & 9.4 & 7.7 & $\begin{array}{l}5.6 \\
9,4^{*}\end{array}$ & $13,1^{\star}$ & $\downarrow 17,9^{*}$ & $\stackrel{-}{(35)}$ \\
\hline 3 & $\begin{array}{l}\text { Share of innovative goods, } \\
\text { works and services in the total } \\
\text { volume of exported goods, } \\
\text { works and services }\end{array}$ & $\%$ & 4.5 & 8.8 & 12.1 & 13.7 & 11.5 & 8.9 & 8.4 & 7.1 & 6.6 & $\downarrow 5.2$ & $\stackrel{-}{(15)}$ \\
\hline 4 & $\begin{array}{l}\text { Intensity of investment in } \\
\text { R\&D of industrial enterprises } \\
\text { (share of R\&D expenditures in } \\
\text { the total costs of production of } \\
\text { goods shipped and execu- } \\
\text { tion of works and services of } \\
\text { industrial enterprises) }\end{array}$ & $\%$ & - & 1.5 & 1.8 & 2.2 & 2.1 & 1.8 & 1.8 & 1.7 & 1.5 & $\downarrow 1.5$ & $\stackrel{-}{(2.5)}$ \\
\hline 5 & $\begin{array}{l}\text { Share of innovative goods, } \\
\text { works and services in the total } \\
\text { volume of goods, works and } \\
\text { services }\end{array}$ & $\%$ & 4.9 & 6.1 & 7.8 & 8.9 & 8.2 & 7.9 & 8.4 & 6.7 & 6.0 & $\downarrow 6.1$ & - \\
\hline 6 & $\begin{array}{l}\text { Share of innovative goods, } \\
\text { works and services of new-to- } \\
\text { market organizations in the } \\
\text { total volume of goods, works } \\
\text { and services of industrial } \\
\text { enterprises }\end{array}$ & $\%$ & 0.8 & 0.6 & 1.1 & 1.1 & 1.1 & 0.9 & 1.0 & 1.3 & 0.9 & $\downarrow 0.6$ & $\overline{(8)}$ \\
\hline 7 & $\begin{array}{l}\text { Share of innovative goods, } \\
\text { works and services that are } \\
\text { new to the global market in } \\
\text { the total volume of goods, } \\
\text { works and services of industri- } \\
\text { al enterprises }\end{array}$ & $\%$ & 0.0 & 0.1 & 0.1 & 0.0 & 0.0 & 0.3 & 0.1 & 0.2 & 0.2 & $\uparrow 0.3$ & $(0.28)$ \\
\hline 8 & $\begin{array}{l}\text { Aggregate level of innova- } \\
\text { tion activity of industrial } \\
\text { enterprises (share of indus- } \\
\text { trial enterprises engaged in } \\
\text { technological, organizational } \\
\text { and/or marketing innovation } \\
\text { activities in the total number } \\
\text { of industrial organizations) }\end{array}$ & $\%$ & 10.8 & 11.1 & 11.1 & 10.9 & 10.9 & 10.6 & 10.5 & $\begin{array}{c}10.6 \\
17,8^{* *}\end{array}$ & $15,6^{\star *}$ & $\downarrow 15,1^{* * *}$ & 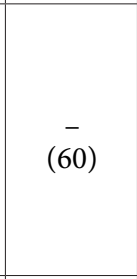 \\
\hline 9 & $\begin{array}{l}\text { Exports and imports of tech- } \\
\text { nologies, }\end{array}$ & $\begin{array}{r}\text { mln US } \\
\text { dollars }\end{array}$ & -798.1 & -1277.9 & -1354.7 & -1693.0 & -1176.6 & -550.7 & -1221.7 & -2124.0 & -1659.3 & $\downarrow-1316.7$ & $\begin{array}{l}\text { (over } \\
300.0)\end{array}$ \\
\hline 10 & $\begin{array}{l}\text { Gross domestic spending on } \\
\text { R\&D, \% of GDP }\end{array}$ & $\%$ & 1.13 & 1.02 & 1.05 & 1.03 & 1.07 & 1.10 & 1.10 & 1.11 & 1.0 & $\downarrow 1.03$ & $\overline{(3)}$ \\
\hline 1 & $\begin{array}{l}\text { Gross domestic spending on } \\
\text { R\&D, by source of funding }\end{array}$ & $\%$ & & & & & & & & & & & \\
\hline & government's funds & & 68.8 & 65.6 & 66.0 & 65.8 & 67.1 & 67.5 & 65.9 & 63.8 & 64.3 & $\downarrow 64.4$ & - \\
\hline & extra-budgetary funds & & 31.2 & 34.4 & 34.0 & 34.2 & 32.9 & 32.5 & 34.1 & 36.2 & 35.7 & $\downarrow 35.6$ & - \\
\hline
\end{tabular}

Source: compiled by the author 
The regional strategy also set the target of expanding the share of innovative goods in the total volume of industrial goods from $5.7 \%$ (in 2011) to $25 \%$ in 2020.

Figure 2 below illustrates the dynamics in this indicator. The highest level in a 5-year period was $10.2 \%$ in 2017 and the indicator did not rise above this level. It is obvious that the figure of $25 \%$ set by the strategy was impossible to reach by 2020 (the actual indicator value was 7.4\%).

One more goal was to increase the domestic expenditures on R\&D as percentage of GRP from $1.2 \%$ (in 2010 ) to $2.5 \%$ in 2020 . Current domestic expenditures on $\mathrm{R} \& \mathrm{D}$ have accounted for $1.15-1.46 \%$ of GRP and so far there has been no indication of further growth. After 2017, the expenditures started to show a decreasing tendency.

In the structure of expenditures, wages and insurance costs account for the largest share. Interestingly, however, there was a colossal increase in the expenditure item 'Other Material Costs' between 2010 and 2017: by 279\%. This fact seems especially remarkable in contrast with the insignificant increase in other types of expenditures. After 2017, the share of this kind of expenditures is gradually declining but it is still a prominent category in the expenditures' structure. At the same time the expenditure level of $2.5 \%$ of GRP until 2020 set by the Strategy remained unachievable.
Share of innovative goods, works and services in the total volume of exported goods, works and services

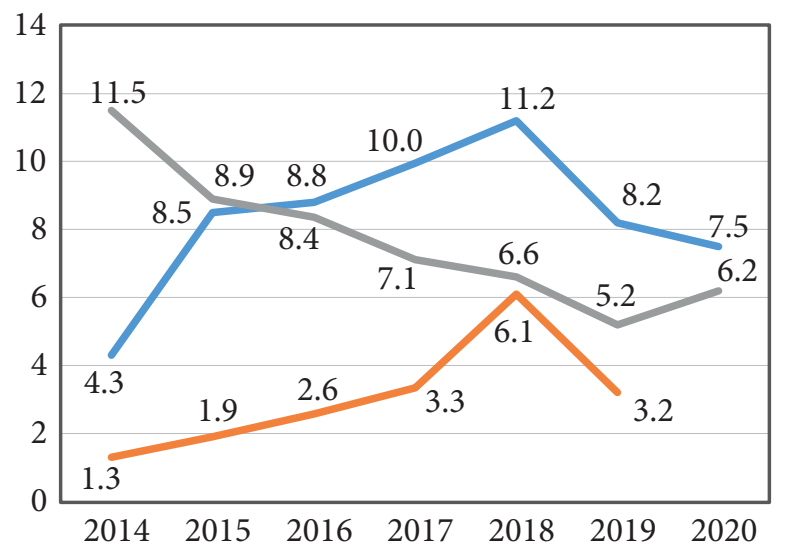

Share of innovative goods, works and services of new-to-market organizations in the total volume of goods, works, and services industrial production

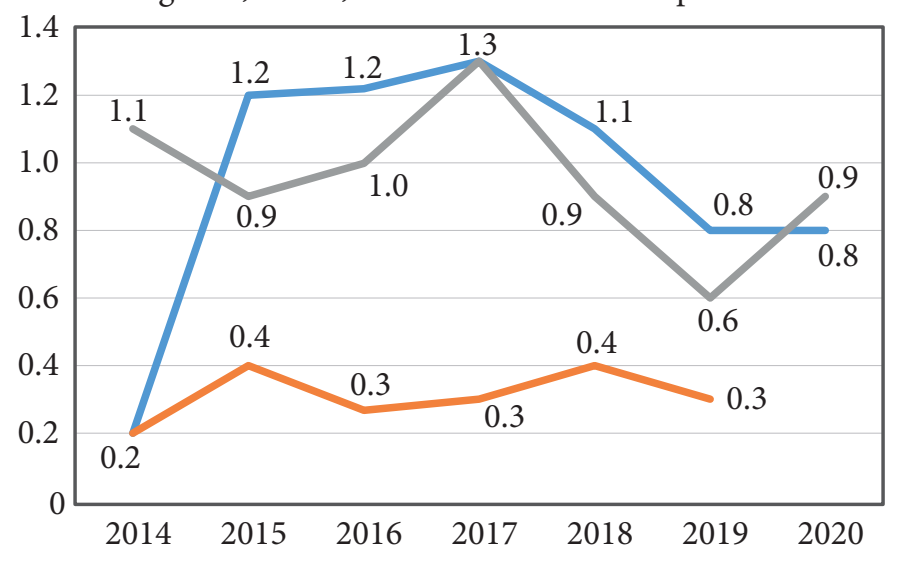

Sverdlovsk region $\quad$ Ural Federal Region $\quad$ Russian Federation

Figure 1. Shares of innovative goods, works, services of industrial enterprises in Sverdlovsk region Source: compiled by the author

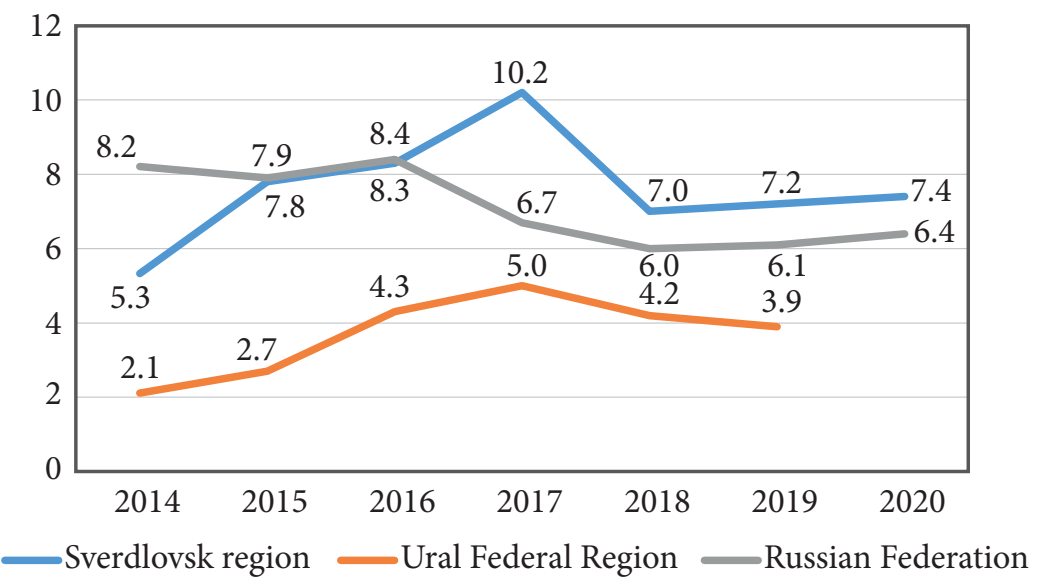

Figure 2. Share of innovative goods, works, services in the total volume of goods, works and services of industrial enterprises

Source: compiled by the author 
Since 2000, the R\&D staff numbers shrank by 6.7 thousand people. The most significant decline was observed in the number of researchers 3.2 thousand people $(25.7 \%)$ - while the number of auxiliary staff remained virtually unchanged: 7.8 thousand people in 2000 and 7.5 thousand people in 2020 (this phenomenon is described by Bochko (2019) as the 'shrinkage' of $R \& D$ personnel).

The Investment Strategy of Sverdlovsk Region until $2035^{3}$ was adopted in 2019. A special emphasis was laid on the growth in the amount of investment. Since 2012, however, the growth of investment has come to a halt and the index of physical volume of investment in fixed capital has started to decline: from $98 \%$ in 2021 to $85.1 \%$ in 2015 and $91.4 \%$ in 2017 . The trend was reversed in 2018, when a number of large investment projects were launched in the region. In 2020, however, investment flows plunged again due to the COVID-19 pandemic. In 2020, the volume of investment in fixed capital was 381.1 billion roubles or $97.2 \%$ of the level of 2019 in comparable prices.

Investments of large and medium-sized enterprises make up the largest part of the investment volume (295.4 billion roubles or $77.5 \%$ ). These enterprises operate in such sectors as manufac-

3 Decree of the Government of Sverdlovsk Region of 15.08.2019 No. 535-ПП 'On the Approval of the Investment Strategy of Sverdlovsk Region until 2035'. turing (71.1 billion); transportation and storage ( 56.5 billion); real estate (45.3 billion); electricity, gas, steam and air conditioning supply (21.6 billion); and ICTs (18.6 billion).

Metallurgy accounts for approximately a half in the structure of investment by type of activity in the manufacturing sector - 49.3\%; production of vehicles and equipment, 14.2\%; other kinds of manufacturing, 9.3\%; production of ready-made metal products, except machinery and equipment, $8.8 \%$.

Enterprises' own funds remain the main source of fixed capital investment. The share of these funds in the total structure of investment has remained relatively stable in the last 20 years, demonstrating a steady, although modest increase and reaching the current level of over $61 \%$. The share of government investment declined in 2015-2020. After 2020, the trend went upward, reaching $17.5 \%$ of federal investment and regional budgets (Table 4 ).

The main trend in the change of the investment structure by form of ownership was a twofold decline in the share of state property from $33.7 \%$ in 2000 to $15.8 \%$ in 2020 . In the same period, the share of private investment almost doubled: from $24.7 \%$ in 2000 to $50.7 \%$ in 2020 (Table 5). The effect from investment in any economic sector and enterprise is determined by the structure of investment according to types of fixed assets.

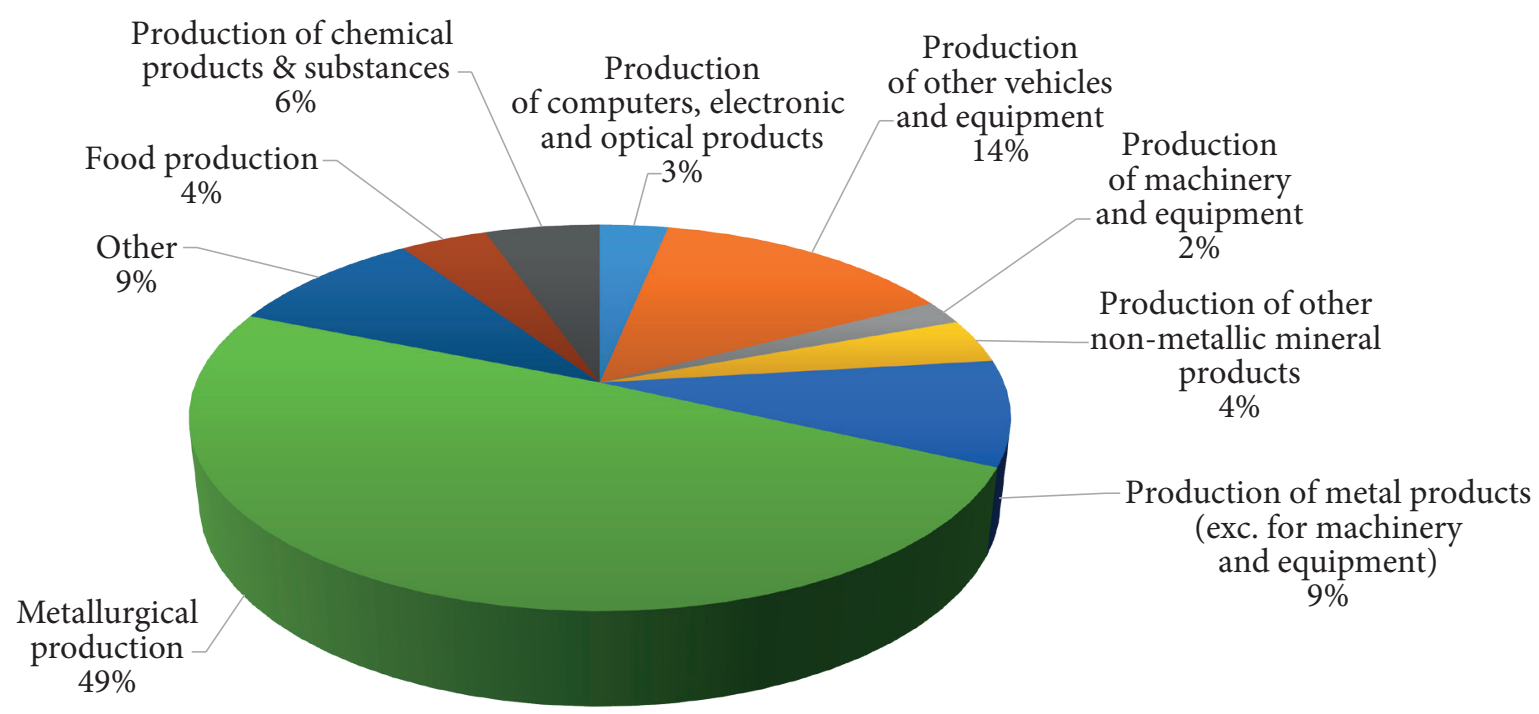

Figure 3. Structure of investment in fixed capital by type of activity of industrial enterprises in January-December 2020 (large and medium-sized enterprises) in \% of the volume of investment in the manufacturing sector

Source: compiled by the author 
Investment into the active part of fixed capital, primarily machinery and equipment, $\mathrm{R} \& \mathrm{D}$, and advanced technologies, is the key to rapid technological change. In Sverdlovsk region, however, only a half of the investment is spent on these goals while investment into production facilities and buildings makes up over $30 \%$, thus reflecting the region's industrial heritage. Investment in machinery and equipment accounts for $55.2 \%$, showing a $6.7 \%$ increase in the last 5 years, which is clearly not enough in view of the enormous obsolescence of fixed assets.
Depreciation of fixed assets in Sverdlovsk region is above $52 \%$, which is higher than the national average by $14.9 \%$. A fairly high rate of depreciation of fixed assets is characteristic of the region's manufacturing enterprises, although their depreciation level remains almost the same as the national average $-48 \%$. The growing depreciation trend in manufacturing seriously impedes the prospects of a rapid technological transformation.

The main goals, targets, industrial and regional growth points are specified in the new Strategy of Industrial and Innovation Development of

Structure of fixed capital investment in Sverdlovsk region, by source of funding (\% of total)

\begin{tabular}{|c|c|c|c|c|c|c|c|}
\hline & \multicolumn{7}{|c|}{ Years } \\
\hline & 2000 & 2014 & 2015 & 2016 & 2017 & 2018 & 2020 \\
\hline Fixed capital investment - total & 100 & 100 & 100 & 100 & 100 & 100 & 100 \\
\hline $\begin{array}{l}\text { Including: } \\
\text { by source of funding } \\
\text { organizations' own funds }\end{array}$ & 62.7 & 48.1 & 46.7 & 54.3 & 58.7 & 58.4 & 61.3 \\
\hline external funds & 37.3 & 51.9 & 53.3 & 45.7 & 41.3 & 41.6 & 38.7 \\
\hline $\begin{array}{l}\text { Including: } \\
\text { bank loans }\end{array}$ & $\ldots$ & 13.7 & 14.6 & 13.5 & 10.3 & 5.4 & 6.6 \\
\hline loans from other lenders & $\ldots$ & 1.8 & 3.6 & 1.5 & 1.6 & 4.6 & 2.9 \\
\hline foreign investment & & 0.0 & 0.7 & 0.2 & 0.1 & 0.2 & 0.1 \\
\hline government funds & 23.9 & 18.2 & 13.6 & 11.9 & 14.5 & 14.1 & 17.5 \\
\hline $\begin{array}{l}\text { Including: } \\
\text { funds from the federal government }\end{array}$ & 5.7 & 10.4 & 5.2 & 4.9 & 7.1 & 5.6 & 5.9 \\
\hline funds from regional governments & 14.1 & 5.1 & 5.7 & 4.7 & 4.9 & 5.5 & 6.6 \\
\hline extra-budgetary funds & $\ldots$ & 0.1 & 0.1 & 0.1 & 0.1 & 0.2 & 0.2 \\
\hline $\begin{array}{l}\text { funds of organizations and individuals } \\
\text { for co-funded construction }\end{array}$ & $\cdots$ & 4.3 & 5.5 & 4.9 & 4.6 & 6.4 & 4.6 \\
\hline other & $\ldots$ & 13.8 & 15.2 & 13.6 & 10.1 & 10.7 & 6.8 \\
\hline
\end{tabular}

Source: compiled by the author.

Table 5

Structure of fixed capital investment in Sverdlovsk region, by form of ownership (\% of total)

\begin{tabular}{|c|c|c|c|c|c|c|c|}
\hline & \multicolumn{7}{|c|}{ Years } \\
\hline & 2000 & 2014 & 2015 & 2016 & 2017 & 2018 & 2020 \\
\hline Fixed capital investment - total & 100 & 100 & 100 & 100 & 100 & 100 & 100 \\
\hline $\begin{array}{l}\text { Including: } \\
\text { by form of ownership } \\
\text { Russian }\end{array}$ & 79.6 & 84.5 & 84.8 & 82.6 & 85.3 & 86.8 & 86.4 \\
\hline $\begin{array}{l}\text { Including: } \\
\text { state }\end{array}$ & 33.7 & 12.9 & 12.1 & 12.4 & 15.0 & 13.2 & 15.8 \\
\hline municipal & 10.2 & 5.5 & 5.5 & 5.3 & 5.2 & 5.9 & 8.1 \\
\hline private & 24.7 & 49.5 & 55.9 & 51.7 & 52.0 & 54.7 & 50.7 \\
\hline consumer cooperatives & 0.0 & 0.0 & 0.0 & 0.0 & 0.0 & 0.0 & 0.0 \\
\hline $\begin{array}{l}\text { public and religious organizations } \\
\text { (associations) }\end{array}$ & 0.2 & 0.0 & 0.0 & 0.0 & 0.0 & 0.0 & 0.0 \\
\hline mixed Russian & 10.8 & 7.7 & 5.7 & 8.9 & 10.8 & 10.7 & 11.1 \\
\hline state corporations' ownership & $\ldots$ & 8.9 & 5.6 & 4.3 & 2.3 & 2.3 & 0.7 \\
\hline foreign & 0.5 & 4.2 & 5.4 & 5.4 & 6.9 & 3.8 & 9.0 \\
\hline joint Russian and foreign & 19.9 & 11.3 & 9.8 & 12.0 & 7.8 & 9.4 & 4.6 \\
\hline
\end{tabular}

Source: compiled by the author 
Sverdlovsk Region until 2035. In the Middle Urals, over $80 \%$ of the output is provided by three industries: metallurgy, mechanical engineering (primarily heavy engineering) and chemical industry. Analysis of the spatial distribution of industrial production assets in Sverdlovsk region shows that the municipalities with a long prior history of industrial development have now become centres of industrial agglomerations - the city of Ekaterinburg, Gornozavodskoy administrative-territorial district, and the northern urban agglomeration. A separate, fourth production zone is located in the town of Kamensk-Uralsky.

The Strategy's priorities are determined for specific industries and territories. The Strategy also specifies the growth points which could be used to enhance the competitive advantages of the mechanical engineering industry on the global high tech market. In this industry, most production facilities are concentrated in the regional centre - Ekaterinburg (it has over $40 \%$ of enterprises, accounting for about $33 \%$ of the industry's output and employing about $35 \%$ of the staff). In total, in Sverdlovsk region there are over 200 mechanical engineering enterprises. In 2020, mechanical engineering accounted for $19.8 \%$ of the output of the region's manufacturing sector while the total output of the industry exceeded 412.8 billion roubles.

The period of investment implementation is crucial for its effective use. The choice of growth points as priorities for investment is of prime importance.

In order to get a clearer picture of the spatial distribution of investment in the region, its administrative-territorial districts and municipalities were ranked by the amount of investment in 2010 and 2020. The total amount of investment from all sources was 2,674,359,675 thousand rou- bles, including $1,276,655,897$ thousand roubles in Ekaterinburg and 1,397,703,778 thousand roubles in other municipalities (see Figure 4 above). The industrial areas and large industrial cities, with Ekaterinburg at the top, occupied the highest positions in terms of fixed capital investment in the given period. Most investment is concentrated in the region's industrial agglomerations with a long prior history of industrial development.

The ranking of territories by the amount of federal and regional fixed capital investment in 2010-2020 has showed the following picture. Most of the investment in fixed capital was also concentrated in industrial agglomerations and large cities. The data on municipalities, however, have shown significant overlaps in the municipalities at the bottom of both rankings (total fixed capital investment and government investment) (see Table 6 below). For example, most of the investment, both total investment and government investment, in the given period was received by Ekaterinburg while Pelym was the municipality that got the least. The top five municipalities are also the same in both rankings. Similarly, three out of five municipalities at the bottom of the list are the same in both rankings - Pelym, Makhnevo, and Malyshevsky. There are multiple similar overlaps throughout both rankings.

The analysis of the spatial aspect of investment in Sverdlovsk region brings us to the following conclusions: first, spatially, investment follows a pattern where most funds are concentrated in large cities and agglomerations, in other words, the sites where the main production assets are located; and, second, large private investments in a particular area tend to draw or attract large government investment to this area (this feature may be referred to as the area's attractiveness to investment).

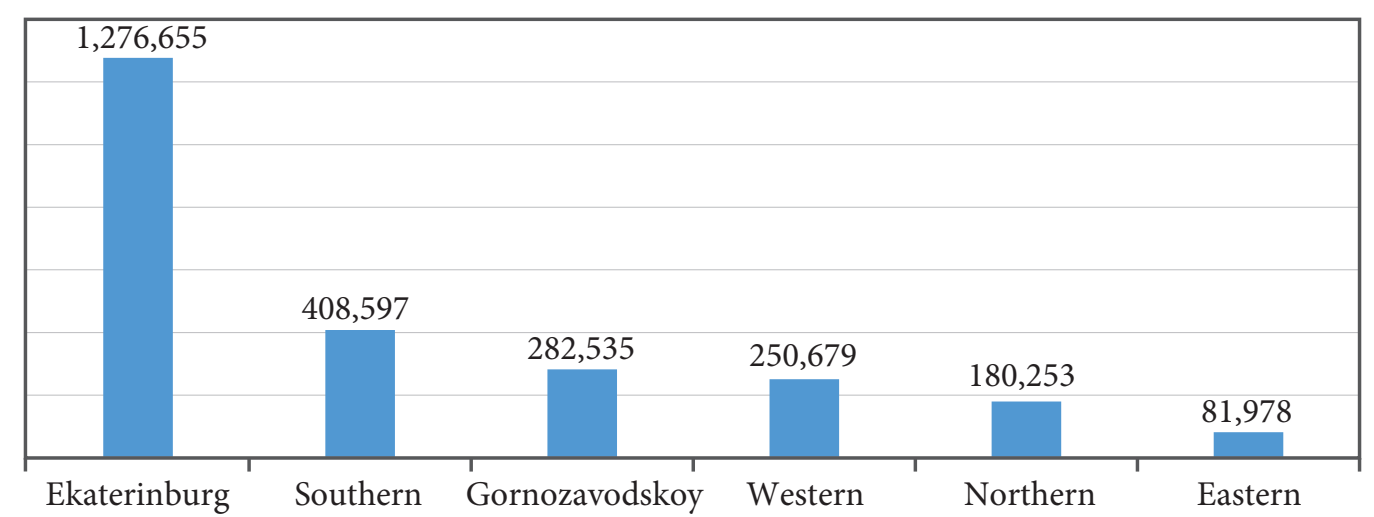

Figure 4. Ranking of administrative-territorial districts by the amount of investment in 2010-2020, mln rbs Source: compiled by the author 
Comparative analysis of municipalities by fixed capital investment in 2010-2020

Table 6

(aggregate investment and government investment)

\begin{tabular}{|c|c|c|}
\hline \multicolumn{3}{|c|}{$\begin{array}{l}\text { Ranking of municipalities by fixed capital investment } \\
\text { in 2010-2020 (large and medium-sized enterprises), } \\
\text { ths rbs }\end{array}$} \\
\hline Position & Municipalities & Total \\
\hline 1 & Ekaterinburg (city) & $1,276,655,897$ \\
\hline 2 & Nizhny Tagil (city) & $174,345,682$ \\
\hline 3 & Zarechny (urban district) & $148,111,618$ \\
\hline 4 & Kamensk-Uralsky (town) & $106,544,657$ \\
\hline 5 & Verkhnyaya Pyshma (urban district) & $85,450,759$ \\
\hline \multicolumn{3}{|c|}{$\begin{array}{l}\text { Ranking of municipalities by fixed capital investment } \\
\text { in 2010-2020 (large and medium-sized enterprises), } \\
\text { ths rbs }\end{array}$} \\
\hline 65 & $\begin{array}{l}\text { Verkhneye Dubrovo (urban district) } \\
\left(54^{\text {th }} \text { in the ranking by budget size }\right)\end{array}$ & 898,199 \\
\hline 66 & Malyshevsky urban district & 527,601 \\
\hline 67 & $\begin{array}{l}\text { Staroutkinsk (urban district) }\left(62^{\text {nd }}\right. \\
\text { in the ranking by budget size) }\end{array}$ & 399,752 \\
\hline 68 & Makhnevo (municipality) & 178,590 \\
\hline 69 & Pelym (urban district) & 123,311 \\
\hline
\end{tabular}

Ranking of municipalities by the amount of government investment in total fixed capital investment in 2010-2020, ths rbs

\begin{tabular}{|c|l|r|}
\hline Position & \multicolumn{1}{|c|}{ Municipalities } & $\begin{array}{c}\text { Total } \\
\text { government } \\
\text { investment }\end{array}$ \\
\hline 1 & Ekaterinburg (city) & $151,468,362$ \\
\hline 2 & Zarechny (urban district) & $63,639,157$ \\
\hline 3 & Nizhny Tagil (city) & $18,738,635$ \\
\hline 4 & Verkhnyaya Pyshma (urban district) & $9,790,450$ \\
\hline 5 & Kamensk-Uralsky (town) & $4,961,296$ \\
\hline
\end{tabular}

Ranking of municipalities by the amount of government investment in total fixed capital investment in 2010-2020,

\begin{tabular}{|c|l|r|}
\multicolumn{2}{|c|}{\begin{tabular}{c} 
ths rbs \\
\hline 65
\end{tabular}} & Makhnevo (municipality) \\
\hline 66 & Verkhny Tagil (urban district) & 82,218 \\
\hline 67 & Malyshevsky (urban district) & 80,924 \\
\hline 68 & $\begin{array}{l}\text { Bisert (urban district) (58 } \\
\text { ranking in the }\end{array}$ & 71,552 \\
\hline 69 & Pelym (urban district) & 70,308 \\
\hline
\end{tabular}

\section{Conclusion}

The study has proven the viability of the proposed methodology based on a combination of statistical methods, methods of quantitative and qualitative analysis of national and regional strategies with a particular focus on the sectoral and spatial aspects.

It was found that on the national level, the general dynamics of innovation was fairly steady between 2010 and 2020. In some areas (technology imports, innovation, patent activity), the trends were mostly negative. As far as the national strategy is concerned, the priorities of innovation development and the upper bound for the key indicators were set correctly - these targets fully reflected the challenges of the technological change that the country had to go through.

The analysis has also revealed the lack of effective mechanisms necessary for the implementation of the national strategy and control over this process. Moreover, the document said nothing about feedback from the regions while feedback is crucial to ensure the federal government's adequate and prompt responses to the problems that may occur in the process.

On the regional level, the analysis focused on the case of Sverdlovsk region and its Strategy of Innovation Development until 2020. It was found that the target values of the indicators were set correctly from the strategic perspective but they were unrealistic from the tactical point of view.

The regional strategy failed to set reference points to guide decision-making in the innovation sphere and thus it did not play the intended role of a comprehensive document for the intensification of innovation processes in the region.

In the way similar to the federal strategy, its regional counterpart failed at the execution stage due to the lack of implementation mechanisms and the insufficient amount of investment.

A more recent document, the Investment Strategy of Sverdlovsk Region until 2035 is mostly declarative as it does not align the measures for the region's industrial and innovative development with the corresponding national programs and does not consider exports. Moreover, the investment strategy lacks a clearly defined aim and does not specify even a minimum set of priorities for the region's industrial development. The investment strategy also fails to provide any guidelines regarding the sources of funding and 
priority areas for investment in the core industries and technologies. Neither does the strategy mention any 'anchor investors' that the region should rely on in the long term and that should thus be entitled to the maximum state support.

The features of Sverdlovsk region's strategies of investment and industrial development until 2035 that appear worthy of special attention are as follows: first, priority-setting underlying these strategies relies on a multitude of approaches and encompasses particular economic sectors, innovation priorities, production technologies, the goals set in the National Technological Initiative, the Governor's 5-year development program, national projects, and so on. Second, the priorities of industrial and innovation development are not aligned with those of the investment strategy. Finally, these strategies do not take into account the export orientation of the industrial policy.

The proposed methodology was used to conduct a comprehensive analysis of the regional policies for investment, innovation and industrial development. The analysis shed light on the 'pain points' of the investment and innovation spheres and the lack of alignment between the strategies both in terms of the vertical (federal and regional levels) and horizontal coordination (coordination between the actors operating within the territory of one region). It was found that the strategy delineating the priorities and indicators of the higher, federal level is not decomposed into mutually aligned goals, targets, priorities and steps on the regional level. Moreover, these documents fail to specify the sources of investment and do not take into account the region's industrial and territorial characteristics. Similarly, regional investment, industrial and innovation strategies are not aligned with each other and thus fail to ensure successful channeling of the resources to priority sectors and to stimulate technological development in the long run.

Analysis of investment in Sverdlovsk region has shown that most investment is concentrated in the region's old industrial areas. Moreover, it was found that there is a direct correlation between the amount of government investment and private investment in these areas.

\section{References}

Abalkin, L.I. (2002). Logic of economic growth. Moscow: Institute of Economics, Russian Academy of Sciences, 228. (In Russ).

Adams, J.S., VanDrasek, B.J., \& Phillips, E.G. (1999). Metropolitan area definition in the United States. Urban Geography, 20(8), 695-726. doi: 10.2747/0272-3638.20.8.695

Aganbegyan, A.G. (2021). Why new Russia needs planning. Voprosy politicheskoy ekonomii = Questions of Political Economy, 2(26), 27-44. (In Russ.) doi: 10.5281/zenodo.5040286

Animitsa, E.G., \& Silin, Y.P. (2013). The Middle Urals on the way to new industrialization. Ekonomika regiona = Economy of Regions, 3(35), 71-81. (In Russ.)

Barinova, V.A., \& Zemtsov, S.P. (2016). Innovation cycle as a base model of the dynamics and organization of innovation activity. Journal of the Institute of Economics of the Russian Academy of Sciences, 1, 117-127. (In Russ.)

Barinova, V.A., Zemtsov, S.P., \& Sorokina, A.V. (2015). Innovation activity of fast-growing companies for the enhancement of their competitiveness. Ekonomika nauki = Economics of Science, 3, 175-179. (In Russ.)

Bochko, V.S. (2011). Conditions and factors of innovation development of municipalities. In: Tatarkin, A.I. (ed.) Innovation Development of the Economics of Science (pp. 133-149). Ekaterinburg: Institute of Economics, Ural Branch of the Russian Academy of Sciences. (In Russ.)

Bochko, V.S. (2015). Positive and negative factors of coordinated and balanced regional development. Ekonomika regiona = Economy of Regions, 1, 39-52. (In Russ.) doi: 10.17059/2015-1-4

Bochko, V.S. (2019). The scientific and research forces of society and their development in the regions. Ekonomika regiona = Economy of Regions, 3, 644-658. (In Russ.) doi: 10.17059/2019-3-2

Borisov, V.N., Pochukaeva, O.V., \& Pochukaev, K.G. (2018). The role of heavy engineering in the process of diversification of regional economies. Voprosy territorialnogo razvitia $=$ Questions of Territorial Development, 5(45). (In Russ.) doi: 10.15838/tdi.2018.5.45.3

Bosák, V., Nováček, A., \& Slach, O. (2018). Industrial culture as an asset, barrier and creative challenge for restructuring of old industrial cities: case study of Ostrava (Czechia). GeoScape, 12(1), 52-64. doi: $\underline{10.2478 / \text { geosc-2018-0006 }}$ 
Coates, V., Farooque, M., Klavans, R., Lapid, K., Linstone, H.A., Pistorius, C., \& Porter, A.L. (2002). On the Future of Technological Forecasting. Technological Forecasting and Social Change, 67(1), 1-17. doi: $10.1016 /$ S0040-1625(00)00122-0

Dezhina, I., \& Ponomarev, A. (2016) Approaches to the Formulation of Russia's Technological Priorities. Foresight and STI Governance, 10(1), 7-15. doi: 10.17323/1995-459X.2016.1.7.15

Frolov, A.S. (2015). Problems of coordination of the state innovation policy. In: Proceedings of the 15th International Conference on the Problems of Development of Economics and Society (pp. 289-300). Moscow: Publishing House of the Higher School of Economics. (In Russ.)

Golichenko, O.G. (2011). Main factors of development of the national innovation system: lessons for Russia. Moscow: Nauka, 633. (In Russ.)

Golova, I.M., \& Sukhovey, A.F. (2011). Spatial aspects of regional innovation policy. In: Tatarkin, A.I. (ed). Innovation Development of the Economics of Science (pp. 149-174). Ekaterinburg: Institute of Economics, Ural Branch of the Russian Academy of Sciences. (In Russ.)

Gordon, G.I. (1993). Strategic Planning for Local Government. Washington. ICMA, 119.

Hassink, R., Isaksen, A., \& Trippl, M. (2019). Towards a comprehensive understanding of new regional industrial path development. Regional Studies, 53(11), 1636-1645. doi: $\underline{10.1080 / 00343404.2019 .1566704}$

Ivanova, O.Y. (2017). Trends of development and distribution of production forces in the Ural macro-region. Upravlanie ekonomicheskimi sistemami: online academic journal = Management of Economic Systems, 9(103), 18. (In Russ.)

Ivanter, V.V. (2017) Structural-investment policy for stimulating economic growth in Russia. Moscow: Nauchny konsultant, 196. (In Russ.)

Kemp, R.I. (1992). Strategic Planning in Local Government (a case book). New York Routledge, 185. doi: $10.4324 / 9781351179041$

Komkov, N.I. (2003). The role of innovation and technologies in the development of economy and society. Problemy prognozirovania = Issues of Forecasting, 3, 24-43. (In Russ.)

Kotlyarova, S.N., Lee, V.A., \& Suvorova, A.V. (2010). Innovation and investment regional infrastructure: factors, trends, and approaches to development in the current conditions. Ekaterinburg: Institute of Economics of the Ural Branch of the Russian Academy of Sciences, 63. (In Russ.)

Lane, N., \& Kalil, T. (2005) The National Nanotechnology Initiative: Present at the Creation. Issues in Science and Technology, 21(4), 49-55.

Martin, B.R. (2010) The Origins of the Concept of "Foresight" in Science and Technology: An Insider's Perspective. Technological Forecasting and Social Change, 77(9), 1438-1447. doi: 10.1016/j.techfore.2010.06.009

Maslennikov, M.I. (2015). Priorities of development of foreign economic relations between Ural regions and BRICS countries. Ekonomika regiona = Economy of Regions, 2, 95-112. (In Russ.) doi: $10.17059 / 2015-2-8$

Medvedev, D.A. (2018). Russia - 2024: Strategy of Socio-Economic Development. Voprosy ekonomiki $=$ Questions of Economics, 10, 5-28. (In Russ.) doi: 10.32609/0042-8736-2018-10-5-28

Porter, M.E. (1996). Competitive advantage, agglomeration economies, and regional policy. International regional science review, 19(1-2), 85-90.

Sidorov, M.A. (2020). Territorial development based on stimulation of the Russian electronics industry. Problemy razvitia territorii $=$ Problems of Territorial Development, 3(107), 27-44. (In Russ.) doi: $10.15838 /$ ptd.2020.3.107.2

Silin, Ya.P., Animitsa, E.G., \& Novikova, N.V. (2019). Ural macro-region: big cycles of industrialization. Ekaterinburg: Publishing House of the Ural State Economic University, 371. (In Russ.)

Silin, Ya.P., Animitsa, E.G., \& Novikova, N.V. (2016). New normality in the Russian economy: regional specifics. Ekonomika regiona = Economy of Regions, 3, 714-725. (In Russ.) doi: $\underline{10.17059 / 2016-3-9}$

Silin, Ya.P., \& Animitsa, E.G. (2021). Reflections on contemporary economic development of Russia. In: Istomina N.A. (ed.) New industrialization of Russia: economy - science - man. Proceedings of the $8^{\text {th }}$ Ural Academic Readings of Professors and Postdoctoral Researchers in Social Sciences (pp. 3-10). Ekaterinburg: Publishing House of the Ural State Economic University. (In Russ.) 
Simachev, Yu., Kuzyk, M., Kuznetsov, B., \& Pogrebnyak, E. (2014). Russia on the path towards a new technology industrial policy: exciting prospects and fatal traps. Foresight-Russia, 8(4), 6-23.

Smit, P., \& Moore, P. (1993). Cities as social responsibility: Planning and urban form. In: Bourne, L., Ley, D. (ed.) The changing social geography of Canadian cities (pp. 343-367). Montreal: McGill-Queen's University Press.

Tatarkin, A.I. (ed.) (2016). Breakthrough into the future. Innovation profile of the Ural metaregion. Ekaterinburg: Institute of Economics, Ural Branch of the Russian Academy of Sciences, 274. (In Russ.)

Vasiliev, Y.P. (2009). Innnovative management of production development in the USA or how to boost labour productivity. Moscow: Ekonomika, 446. (In Russ.)

Vlasov, S.V. (2018). Industrial policy of Sverdlovsk region: critical analysis. Gosudarstvennaya sluzhba = Public Administration, 3(113), 50-55. (In Russ.) doi: 10.22394/2070-8378-2018-20-3

Vlasov, S.V. (2019). Factors of development of the innovation potential of enterprises of an industrial region (the case of the city of Nizhny Tagil). Journal of the Ural Federal University. Series: Economics and Management, 18(6), 826-853. (In Russ.) doi: 10.15826/vestnik.2019.18.6.040

Vlasov, S.V., Temkina, I.M., Lukyanov, S.A. \& Avramenko, E.S. (2015). Regional investment policy in the light of budget constraints and economic sanctions. Ekonomika regiona $=$ Economy of Regions, 1, 213-223. (In Russ.) doi: 10.17059/2015-1-18

Wagner, C., \& Popper, S. (2003). Identifying critical technologies in the United States: A review of the federal effort. Journal of Forecasting, 22(2/3), 113-128. doi: 10.1002/for.854

\section{Information about the authors}

Semyon V. Vlasov - Deputy Minister, Ministry of Agriculture and Consumer Market of the Sverdlovsk Region (620026, Ekaterinburg, Rosa Luxemburg street, 60), e-mail: vlasovsv81@gmail.com

ARTICLE INFO: received September 28, 2021; accepted November 08, 2021

\section{Информация об авторах}

Власов Семен Васильевич - заместитель министра, Министерство агропромышленного комплекса и потребительского рынка Свердловской области (620026, г. Екатеринбург, ул. Розы Люксембург, 60); e-mail: vlasovsv81@gmail.com

ИНФОРМАЦИЯ О СТАТЬЕ: дата поступления 28 сентября 2021 2.; дата принятия к печати 8 ноября 2021 г. 